\title{
Pengaruh Perputaran Piutang Dan Perputaran Aktiva Tetap Terhadap Profitabilitas \\ (Pada Perusahaan Perdagangan Eceran yang Terdaftar di Bursa Efek Indonesia Pada Tahun 2013 - 2017)
}

\author{
Emmi Rhury Agleintan1) \\ Sutrisna2) \\ Sutandi ${ }^{3)}$ \\ Universitas Buddhi Dharma, Banten, Indonesia
}

\begin{abstract}
Abstrak
Penelitian ini bertujuan untuk mengetahui bagaimana pengaruh perputaran piutang terhadap profitabilitas, pengaruh perputaran aktiva tetap terhadap profitabilitas, dan pengaruh perputaran piutang dan perputaran aktiva tetap terhadap profitabilitas pada perusahaan perdagangan eceran yang terdaftar di Bursa Efek Indonesia (BEI). Dimana dalam penelitian ini menggunakan Return On Assets untuk menentukan profitabilitas.

Objek dalam penelitian ini menggunakan laporan keuangan tahunan dari perusahaan terbuka yang merupakan perusahaan jasa, sektor Perdagangan, Jasa dan investasi, dengan sub sektor adalah perdagangan eceran yang terdaftar di Bursa Efek Indonesia (BEI). Sampel yang digunakan yaitu sebanyak tujuh perusahaan dengan periode waktu selama lima tahun berturut-turut, yaitu dari tahun 2013 sampai tahun 2017. Laporan keuangan tahunan diperoleh dari web resmi Bursa Efek Indonesia (BEI) dan The Indonesia Capital Market Institute (TICMI).

Dalam menentukan sampel, penelitian ini menggunakan teknik Purposive Sampling. Analisis yang digunakan dalam penelitian ini adalah analisis statistik deskriptif, analisis regresi berganda, dan uji hipotesis. Dengan menggunakan tingkat signifikansi sebesar 0,05.

Hasil dari penelitian ini menunjukan bahwa, adanya pengaruh perputaran piutang terhadap profitabilitas (ROA) dengan tingkat signifikan sebesar 0,000. Selain itu, terdapat juga adanya pengaruh perputaran aktiva tetap terhadap profitabilitas (ROA) dengan tingkat signifikan sebesar 0,16. Serta adanya profitabilitas (ROA) yang dipengaruhi oleh perputaran piutang dan perputaran aktiva tetap sebesar $41,3 \%$.
\end{abstract}

Kata Kunci : Perputaran Piutang, Perputaran Aktiva Tetap, Profitabilitas (ROA) 


\section{Abstract}

The aim of this research are to know how it affect of receivabel turnover to profitability, affect of fixed assets turnover to profitability, and affect of receivabel turnover and fixed assets turnover to profitability in retail trade company who listed on the Indonesia Stock Exchange (IDX). This research using Return on assets to dicide profitability.

The objects of this research using annual report from company that have go public which is service company, sector of trade, service, and investment, and sub sector of retail trade that have listed on the Indonesia Stock Exchange (IDX). The research's sampels are seven companies and period of time during five years, there are 2013 until 2017. The annual reports are obtained from official website of the Indonesia Stock Exchange (IDX) and The Indonesia Capital Market Institute (TICMI).

The research sample was determined by the method of purposive sampling. The research using analyze of descriptive statistic, multiple linear regression models, and hypothesis testing. The significant is 0,05 .

The result are showing that there is a affect receviabel turnover to profitability (ROA), that have significant impact amount 0,00. There is a affect fixed assets turnover to profitability (ROA), that have significant impact amount 0,16. Profitability (ROA) is influenced by receivable turnover and fixed asset turnover of $41.3 \%$.

\section{Keywords : Receviabel Turnover, Fixed Assets Turnover, Profitability (ROA)}

\section{PENDAHULUAN}

Walaupun adanya perbedaan dalam proses bertransaksi pada zaman dahulu dengan sekarang, tetap saja seseorang atau perusahaan yang melakukan perdagangan (menjual barang) untuk menghasilkan laporan keuangan yang bagus dan baik. Salah satu bagian yang terpenting secara kasat mata dalam laporan keuangan adalah dengan mendapatkan keuntungan yang optimal. Keuntungan, laba, atau disebut juga sebagai profitabilitas yang merupakan hasil dari menjual suatu produk, untuk meningkatkan modal sendiri, meningkatkan nilai perusahaan dan meningkatkan kepuasan investor karena mendapatkan deviden lebih banyak, sehingga akan meningkatkan kepercayaan dan daya tarik para investor untuk menanamkan modalnya kepada perusahaan.

Dalam proses menjual produk, tentunya kita perlu mempersiapkan adanya sumber daya yang mendukung kegiatan usaha. Sumber daya yang dimaksud ini adalah aktiva. Aktiva itu sendiri terbagi menjadi dua, yaitu aktiva tetap dan aktiva lancar. Perbedaan antara aktiva tetap dan aktiva lancar yaitu dari segi waktu manfaatnya. Jika aktiva tetap, masa manfaatnya lebih dari satu tahun, sedangkan aktiva lancar hanya kurang dari satu tahun. Sumber daya yang dimaksud dalam aktiva tetap, yaitu seperti tanah, mesin, bangunan dan lain-lain yang dapat berguna untuk mendukung kegiatan usaha. Walaupun aktiva tetap memiliki masa manfaat yang lama, tapi tetap saja akan terjadi penurunan kinerja, yang biasa disebut dengan penyusutan, sehingga pada waktu tertentu tetap harus menggantikan aktiva tetap yang lama dengan aktiva tetap yang baru demi kelancaran kegiatan usaha. Maka dari itu pemilihan aktiva tetap perlu diperhitungkan dengan tepat, agar tidak terjadi dan mampu mengurangi kerugian yang kemungkinan akan terjadi di perusahaan 
tersebut. Dengan pemilihan aktiva tetap yang tidak tepat maka bisa mengakibatkan kerugian dan mempengaruhi laporan neraca, dimana yang dampaknya akan membuat laba menurun.

Tentu saja jika ingin mendapatkan keuntungan yang besar cara yang paling mudah adalah dengan menjual produk sebanyak-banyaknya dengan memberikan keringanan pembayaran yang dapat dilakukan kemudian hari, atau biasanya disebut dengan piutang. Tetapi pada akhirnya, saat waktunya atau jatuh tempo pembayaran piutang ada saja pihak ketiga atau pembeli yang tidak mampu membayar, sehingga dapat merugikan perusahaan dan mempengaruhi laporan neraca, dimana membuat laba menurun juga.

Objek dari penelitian ini adalah perusahaan terbuka yang merupakan Perusahaan Jasa, sektor Perdagangan, Jasa dan Investasi, dengan sub sektor adalah Perdagangan Eceran yang terdaftar di Bursa Efek Indonesia (BEI). Perdagangan Eceran yang dimaksud adalah perusahaan yang bergerak dibidang distribusi dari produk yang dihasilkan oleh perusahaan manufaktur lalu dipasarkan kepada konsumen akhir.

Tujuan penelitian ini, yaitu: untuk mengetahui bagaimana pengaruh perputaran piutang terhadap profitabilitas. Untuk mengetahui bagaimana pengaruh perputaran aktiva tetap terhadap profitabilitas. Untuk mengetahui bagaimana pengaruh perputaran piutang dan perputaran aktiva tetap terhadap profitabilitas.

\section{LANDASAN TEORI}

\section{Perputaran Piutang (Receviable Turnover)}

Piutang sebagai elemen dari modal kerja selalu dalam keadaan "berputar". Makin lama syarat pembayaran, maka makin lama modal terikat pada piutang, sehingga tingkat perputaran piutang makin rendah. (Musthafa 2017, 41). Rumus yang digunakan adalah sebagai berikut:

\section{Perputaran Aktiva Tetap (Fixed Assets Turnover)}

$$
\text { Peputaran Piutang }=\frac{\text { Penjualan Bersih }}{\text { Rata }- \text { rata }}
$$

Perputaran aktiva tetap atau fixed asset turnover merupakan perbandingan antara penjualan dengan total aktiva tetap yang dimiliki perusahaan. Rasio ini digunakan untuk mengukur efektivitas penggunaan aktiva tetap dalam mendapatkan penghasilan. (Sutrisno 2017, 211). Rumus yang digunakan adalah sebagai berikut:

\section{Profitabilitas}

$$
\text { Perputaran Aktiva Tetap }=\frac{\text { Penjualan Bersih }}{\text { Aktiva Tetap }}
$$

Rasio profitabilitas merupakan rasio untuk menilai kemampuan perusahaan dalam mencari keuntungan. Rasio ini mengukur kemampuan perusahaan untuk menghasilkan laba dengan menggunakan sumber- sumber yang dimiliki perusahaan, seperti aktiva total, modal, atau penjualan perusahaan (Kasmir 2016, 196). Untuk menentukan besarnya rasio profitabilitas dalam penelitian ini, maka peneliti menggunakan Return on Assets, dimana rumusnya sebagai berikut: 


$$
\text { Return on Assets }=\frac{\text { Laba setelah pajak }}{\text { Total Aktiva }}
$$

\section{METODE PENELITIAN}

Penelitian ini merupakan penelitian asosiatif kausal dengan pendekatan kuantitatif. Menurut (Timotius 2017, 16), penelitian asosiatif kausal merupakan penelitian yang bertujuan untuk mengetahui atau menganalisis ada dan tidaknya pengaruh atau hubungan antara dua atau lebih variabel, serta pengaruh atau hubungan antara variabel bebas dengan variabel terikat. Variabel bebas dalam penelitian ini adalah perputaran piutang dan perputaran aktiva tetap. Variabel terikat dalam penelitian ini adalah profitabilitas.

Menurut Sugiyono (Lubis 2018, 48), metode penelitian kuantitatif dapat diartikan sebagai metode penelitian yang berlandaskan pada filsafat positivisme, digunakan untuk meneliti pada populasi atau sampel tertentu.

Pada penelitian ini, jenis data yang dipakai adalah data sekunder yang merupakan data panel. Data sekunder adalah data yang diperoleh dari hasil penelitian orang lain atau dari pusat data (Timotius 2017,69). Data panel terdiri dari data runtut waktu (time series) dan data silang waktu (cross section). Data runtut waktu (time series) adalah data yang dikumpulkan dari waktu ke waktu pada satu objek. Data silang waktu (cross section) adalah data yang dikumpulkan dalam satu waktu dari beberapa obyek. Jadi, data panel adalah data yang dikumpulkan dari beberapa waktu dan beberapa objek. (Ansofino, et al. 2016, 141)

Data penelitian ini berupa dokumen laporan keuangan tahunan dari Perusahaan Jasa, disektor Perdagangan, Jasa dan Investasi, dengan Sub-Sektor Perdagangan Eceran yang terdaftar di Bursa Efek Indonesia. Dokumen laporan keuangan tahunan didapat dari web Bursa Efek Indonesia (www.idx.co.id) yang sudah dipublikasikan dan dapat diunduh secara bebas dan web The Indonesia Capital Market Institute (www.ticmi.co.id). Periode waktu yang peneliti gunakan selama 5 tahun berturut-turut, yaitu tahun 2013 sampai dengan tahun 2017. Data perusahaan sub-sektor perdagangan eceran yang terdaftar di Bursa Efek Indonesia (BEI) yang dijadikan sampel, adalah sebanyak 7 perusahaan. Dimana laporan keuangan yang dikumpulkan dari setiap perusahaan yaitu masing-masing 5 tahun secara berturut-turut dengan periode tahun 2013 sampai dengan tahun 2017, sehingga banyaknya data yang dijadikan penelitian sebanyak 35 data laporan keuangan tahunan.

Berikut adalah sampel yang diteliti dalam penelitian ini:

\begin{tabular}{|l|l|l|l|}
\hline No. & $\begin{array}{c}\text { Kode } \\
\text { Perusahaan }\end{array}$ & \multicolumn{1}{|c|}{ Perusahaan } & $\begin{array}{c}\text { Tahun } \\
\text { IPO }\end{array}$ \\
\hline 1 & AMRT & PT. Sumber Alfaria Trijaya Tbk. & 2009 \\
\hline 2 & CSAP & PT. Catur Sentosa Adiprana Tbk. & 2007 \\
\hline 3 & ERAA & PT. Erajaya Swasembada Tbk. & 2011 \\
\hline 4 & MAPI & PT. Mitra Adiperkasa Tbk. & 2004 \\
\hline 5 & MIDI & PT. Midi Utama Indonesia Tbk. & 2010 \\
\hline 6 & RALS & PT. Ramayana Lestari Sentosa Tbk. & 1996 \\
\hline 7 & TELE & PT. Tiphone Mobile Indonesia Tbk. & 2012 \\
\hline
\end{tabular}


Operasional dalam penelitian ini adalah sebagai berikut:

\begin{tabular}{|c|c|c|c|c|}
\hline & Variabel & Definisi & Rumus & Skala \\
\hline \multirow{2}{*}{$\begin{array}{l}\text { Independe } \\
\mathrm{n}\end{array}$} & $\begin{array}{c}\text { Perputaran } \\
\text { Piutang }\end{array}$ & $\begin{array}{l}\text { Perbandingan } \\
\text { penjualan bersih } \\
\text { dengan rata-rata } \\
\text { piutang dagang }\end{array}$ & $\begin{array}{c}\text { Penjualan Bersih } \\
\text { Rata }- \text { rata } \\
\text { piutang dagang } \\
\text { (Harjito and Martono } \\
\text { 2014) }\end{array}$ & $\begin{array}{c}\text { Rasi } \\
\text { o }\end{array}$ \\
\hline & $\begin{array}{l}\text { Perputaran } \\
\text { Aktiva } \\
\text { Tetap }\end{array}$ & $\begin{array}{l}\text { Perbandingan } \\
\text { antar penjualan } \\
\text { bersih dengan } \\
\text { aktiva tetap }\end{array}$ & $\begin{array}{c}\text { Penjualan Bersih } \\
\text { Aktiva Tetap } \\
\text { (Fahmi 2016) }\end{array}$ & $\begin{array}{c}\text { Rasi } \\
\text { o }\end{array}$ \\
\hline Dependen & $\begin{array}{l}\text { Profitabilita } \\
\text { s } \\
\text { (Return on } \\
\text { Asset) }\end{array}$ & $\begin{array}{c}\text { Perbandingan } \\
\text { laba setelah pajak } \\
\text { dengan total asset }\end{array}$ & $\begin{array}{c}\frac{\text { Laba Setelah Pajak }}{\text { Total Aset }} \\
\text { (Brigham and Houston } \\
\text { 2014) }\end{array}$ & $\begin{array}{c}\text { Rasi } \\
\text { o }\end{array}$ \\
\hline
\end{tabular}

\section{HASIL PENELITIAN DAN PEMBAHASAN}

Analisis Statistik Deskriptif

\begin{tabular}{|l|r|r|r|r|r|r|}
\hline & $\mathrm{N}$ & Minimum & Maximum & \multicolumn{1}{c|}{ Mean } & $\begin{array}{c}\text { Std. } \\
\text { Deviation }\end{array}$ & \multicolumn{1}{c|}{ Variance } \\
\hline Perputaran Piutang & 35 & 6.94 & 2706.73 & 256.2397 & 658.24373 & 433284.811 \\
\hline $\begin{array}{l}\text { Perputaran Aktiva } \\
\text { Tetap }\end{array}$ & 35 & 3.88 & 205.83 & 31.4186 & 50.11281 & 2511.294 \\
\hline Profitabilitas & 35 & 0.32 & 8.92 & 4.2737 & 2.40917 & 5.804 \\
\hline
\end{tabular}

Sumber: Data diolah dengan IBM SPSS Statistics 23, 2018.

1) Jumlah data masing-masing variabel ditunjukan pada kolom $N$, yaitu sebesar 35 data.

2) Nilai minimum atau nilai terendah dari 35 data ditunjukan pada kolom Minimun, yaitu sebesar 6,94 untuk perputaran piutang, 3,88 untuk perputaran aktiva tetap, dan 0,32 untuk perputaran profitabilitas.

3) Nilai maksimum atau nilai tertinggi dari 35 data ditunjukan pada kolom Maximum, yaitu sebesar 2.706,73 untuk perputaran piutang, 205,83 untuk perputaran aktiva tetap, dan 8,92 untuk perputaran profitabilitas.

4) Nilai rata-rata dari 35 data ditunjukan pada kolom Mean, yaitu sebesar 256,2397 untuk perputaran piutang, 31,4186 untuk perputaran aktiva tetap, dan 4,2737 untuk perputaran profitabilitas.

5) Nilai standar deviasi dari 35 data ditunjukan pada kolom Std. Deviation, yaitu sebesar 658,24373 untuk perputaran piutang, 50,11281 untuk perputaran aktiva tetap, dan 2,40917 untuk perputaran profitabilitas.

6) Nilai varian dari 35 data ditunjukan pada kolom Variance, yaitu sebesar 433.284,811 untuk perputaran piutang, 2.511,294 untuk perputaran aktiva tetap, dan 5,804 untuk perputaran profitabilitas. 


\section{Analisis Data}

Model Summary

\begin{tabular}{|l|r|r|r|c|}
\hline $\begin{array}{l}\text { Mod } \\
\text { el }\end{array}$ & R & R Square & \multicolumn{1}{|c|}{$\begin{array}{c}\text { Adjusted R } \\
\text { Square }\end{array}$} & $\begin{array}{c}\text { Std. Error of the } \\
\text { Estimate }\end{array}$ \\
\hline 1 & $.669 \mathrm{a}$ & .447 & .413 & 1.84634 \\
\hline
\end{tabular}

a. Predictors: (Constant), Perputaran Aktiva Tetap, Perputaran

Piutang

Sumber: Hasil Output IBM SPSS Statistics 23, 2018.

a. Analisis Korelasi Ganda (R)

Berdasarkan tabel di atas, dapat dijelaskan bahwa nilai $\mathrm{R}$ sebesar 0,669, maka dapat diartikan bahwa terjadinya hubungan yang kuat antara perputaran piutang dan perputaran aktiva tetap terhadap profitabilitas.

b. Analisis Koefisien Determinasi (Adjusted $\mathbf{R}^{2}$ )

Berdasarkan tabel di atas dapat dijelaskan bahwa nilai Adjusted $\mathrm{R}^{2}$ sebesar 0,413 dimana dalam presentase menjadi $41,3 \%$. Hal ini menunjukan bahwa presentase hubungan varibel bebas (perputaran piutang dan perputaran aktiva tetap) terhadap vairabel terikat (profitabilitas) sebesar $41,3 \%$, sehingga sisanya sebesar $58,7 \%$ (100\%-41,3\%) dipengaruhi oleh variabel lain yang tidak termasuk dalam variabel penelitian ini.

c. Analisis Regresi Berganda

\begin{tabular}{|c|c|c|c|c|c|}
\hline & ffici & & & & \\
\hline \multirow[b]{2}{*}{ Model } & \multicolumn{2}{|c|}{$\begin{array}{l}\text { Unstandardized } \\
\text { Coefficients }\end{array}$} & \multirow{2}{*}{$\begin{array}{c}\begin{array}{c}\text { Standardi } \\
\text { zed } \\
\text { Coefficien } \\
\text { ts }\end{array} \\
\\
\text { Beta } \\
\end{array}$} & \multirow[b]{2}{*}{$t$} & \multirow[b]{2}{*}{ Sig. } \\
\hline & B & $\begin{array}{l}\text { Std. } \\
\text { Error }\end{array}$ & & & \\
\hline 1 (Constant) & 3.150 & .406 & & 7.754 & .000 \\
\hline Perputaran Piutang & .002 & .000 & .650 & 4.839 & .000 \\
\hline $\begin{array}{l}\text { Perputaran Aktiva } \\
\text { Tetap }\end{array}$ & .016 & .006 & .341 & 2.536 & .016 \\
\hline
\end{tabular}

a. Dependent Variable: Profitabilitas

Sumber: Hasil Output IBM SPSS Statistics 23, 2018.

Persamaan regresi berganda akan sebagai berikut:

Keterangan:

$\mathrm{Y}=$ Profitabilitas

$$
Y=\alpha+\beta_{1} X_{1}+\beta_{2} X_{2}+\varepsilon
$$

$$
\begin{aligned}
& X_{1}=\text { Perputaran Piutang } \\
& X_{2}=\text { Perputaran Aktiva Tetap }
\end{aligned}
$$

1) Nilai konstanta sebesar 3,150; artinya jika perputaran piutang dan perputaran aktiva tetap nilainya adalah 0 , maka nilai profitabilitas adalah 3,150.

2) Nilai koefesien regresi variabel perputaran piutang (X1) sebesar 0,002; artinya jika perputaran piutang mengalami kenaikan satu satuan, maka nilai profitabilitas akan mengalami kenaikan sebesar 0,002 satuan dengan asumsi 
variabel perputaran aktiva tetap nilainya tetap.

3) Nilai koefesien regresi variabel perputaran aktiva tetap (X1) sebesar 0,016; artinya jika perputaran aktiva tetap mengalami kenaikan satu satuan, maka nilai profitabilitas akan mengalami kenaikan sebesar 0,016 satuan dengan asumsi variabel perputaran piutang nilainya tetap.

\section{Uji Hipotesis}

a. Uji Koefisien Regresi Secara Simultan (uji F)

ANOVA $^{\mathrm{a}}$

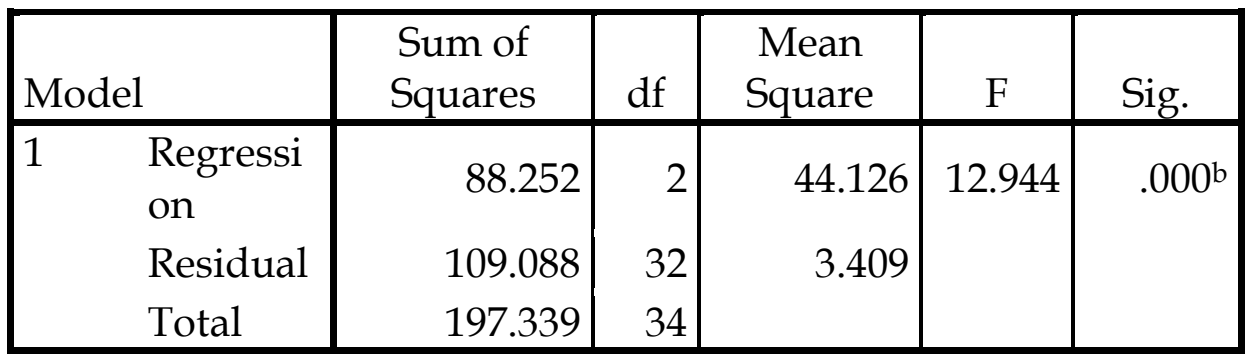

a. Dependent Variable: Profitabilitas

b. Predictors: (Constant), Perputaran Aktiva Tetap, Perputaran

Piutang

Sumber: Hasil Output IBM SPSS Statistics 23, 2018.

Diketahui nilai F tabel sebesar 3,295 dan F hitung sebesar 12,944 (pada kolom F). Dengan demikian dapat disimpulkan bahwa F hitung sebesar 12,944 lebih besar daripada F tabel sebesar 3,295, sehingga dapat diartikan bahwa Ho ditolak dan Ha diterima. Selain itu, berdasarkan Tabel VI.10. dapat dilihat, bahwa nilai signifikan sebesar 0,000 dengan nilai tingkat signifikan lebih kecil dari 0,05, sehingga H3 diterima, yaitu perputaran piutang dan perputaran aktiva tetap secara bersamasama berpengaruh positif signifikan terhadap profitabilitas.

\section{b. Uji Koefisien Regresi Secara Parsial (Uji t)}

\section{Coefficients ${ }^{a}$}

\begin{tabular}{|c|c|c|c|c|c|}
\hline \multirow[b]{2}{*}{ Model } & \multicolumn{2}{|c|}{$\begin{array}{c}\text { Unstandardized } \\
\text { Coefficients }\end{array}$} & \multirow{2}{*}{$\begin{array}{c}\begin{array}{c}\text { Standardized } \\
\text { Coefficients }\end{array} \\
\text { Beta } \\
\end{array}$} & \multirow[b]{2}{*}{$t$} & \multirow[b]{2}{*}{ Sig. } \\
\hline & B & $\begin{array}{l}\text { Std. } \\
\text { Error }\end{array}$ & & & \\
\hline 1 (Constant) & 3.150 & .406 & & 7.754 & .000 \\
\hline Perputaran Piutang & .002 & .000 & .650 & 4.839 & .000 \\
\hline $\begin{array}{l}\text { Perputaran Aktiva } \\
\text { Tetap }\end{array}$ & .016 & .006 & .341 & 2.536 & .016 \\
\hline
\end{tabular}

a. Dependent Variable: Profitabilitas

Sumber: Hasil Output IBM SPSS Statistics 23, 2018.

Diketahui nilai t tabel sebesar 1,694, maka dapat diartikan bahwa:

1) Pengaruh perputaran piutang terhadap profitabilitas 
Dari tabel di atas, diketahui t hitung untuk variabel perputaran piutang sebesar 4,839 , dimana hasil $t$ hitung lebih besar daripada $t$ tabel $(4,839>1,694)$, sehingga dapat diartikan bahwa Ho ditolak dan Ha diterima, dan selain itu memiliki nilai signifikan sebesar 0,000 dengan nilai tingkat signifikan lebih kecil dari 0,05, sehingga $\mathrm{H} 1$ diterima, yaitu perputaran piutang berpengaruh positif signifikan terhadap profitabilitas.

2) Pengaruh perputaran aktiva tetap terhadap profitabilitas

Dari tabel di atas, diketahui $\mathrm{t}$ hitung untuk variabel perputaran aktiva tetap sebesar 2,536, dimana hasil $t$ hitung lebih besar daripada $t$ tabel $(2,536>1,694)$, sehingga dapat diartikan bahwa Ho ditolak dan Ha diterima, dan selain itu memiliki nilai signifikan sebesar 0,016 dengan nilai tingkat signifikan lebih kecil dari 0,05, sehingga $\mathrm{H} 2$ diterima, yaitu perputaran aktiva tetap berpengaruh positif signifikan terhadap profitabilitas.

\section{PEMBAHASAN}

\section{Pengaruh Perputaran Piutang terhadap Profitabilitas}

Berdasarkan hasil analisis statistik deskriptif variabel perputaran piutang memiliki nilai minimal sebesar 6,94; nilai maksimal sebesar 2.706,73, nilai rata-rata sebesar 256,2397, nilai standar deviasi sebesar 658,24373 dan nilai varian sebesar 50,11281 .

Berdasarkan hasil pengujian analisis regresi berganda variabel perputaran piutang memiliki nilai sebesar 0,002, yang menunjukkan bahwa setiap adanya perubahan satu satuan perputaran aktiva tetap maka nilai profitabilitas akan mengalami kenaikan sebesar 0,002 satuan dengan asumsi variabel perputaran aktiva tetap nilainya tetap.

Berdasarkan hasil pengujian secara parsial (uji t) variabel perputaran piutang terhadap profitabilitas, dapat kita lihat bahwa hasil $t$ hitung sebesar 4,839 dan $t$ tabel sebesar 1,694, dimana hasil $t$ hitung lebih besar daripada $t$ tabel $(4,839>1,694)$ dan memiliki nilai signifikan sebesar 0,000 dengan nilai tingkat signifikan lebih kecil dari 0,05, sehingga dapat diartikan bahwa perputaran piutang berpengaruh positif signifikan terhadap profitabilitas. Hal ini sejalan dengan penelitian yang sudah lakukan sebelumnya oleh Hoiriya \& Lestariningsih (2015), Ainiyah \& Khuzaini (2016), dan Verawati \& Oetomo (2014) yang menyatakan bahwa perputaran piutang memberikan pengaruh yang signifikan terhadap profitabilitas. Hasil dari pengujian ini membuktikan bahwa semakin tinggi tingkat perputaran piutang maka perusahaan akan beroprasi dengan baik dikarenakan hasil dari penjualan kredit akan cepat masuk menjadi kas, dimana kas tersebut dapat meningkatkan profitabilitas dan dapat digunakan kembali untuk kelancaran operasional perusahaan.

\section{Pengaruh Perputaran Aktiva Tetap Terhadap Profitabilitas}

Berdasarkan hasil analisis statistik deskriptif variabel perputaran aktiva tetap memiliki nilai minimal sebesar 3,88, nilai maksimal sebesar 205,83, nilai rata-rata sebesar 31,4186, nilai standar deviasi sebesar 433.284,811 dan nilai varians sebesar $2.511,294$. 
Berdasarkan hasil pengujian analisis regresi berganda variabel perputaran aktiva tetap memiliki nilai sebesar 0,016, yang menunjukkan bahwa setiap adanya perubahan satu satuan perputaran piutang maka nilai profitabilitas akan mengalami kenaikan sebesar 0,016 satuan dengan asumsi variabel perputaran piutang nilainya tetap.

Berdasarkan hasil pengujian secara parsial (uji t) variabel perputaran aktiva tetap terhadap profitabilitas, dapat kita lihat bahwa hasil $t$ hitung sebesar 2,536 dan $\mathrm{t}$ tabel sebesar 1,694, dimana hasil $\mathrm{t}$ hitung lebih besar daripada $\mathrm{t}$ tabel $(2,536>$ 1,694), dan memiliki nilai signifikan sebesar 0,016 dengan nilai tingkat signifikan lebih kecil dari 0,05, sehingga dapat diartikan bahwa perputaran aktiva tetap berpengaruh positif signifikan terhadap profitabilitas. Hal ini sejalan dengan penelitian yang sudah lakukan sebelumnya oleh Oxtaviana \& Khusbandiyah (2016), Sodiq \& Fitria (2015), dan Zatira (2017) yang menyatakan bahwa perputaran aktiva tetap memberikan pengaruh yang signifikan terhadap profitabilitas. Hasil dari pengujian ini membuktikan bahwa semakin tinggi tingkat perputaran aktiva tetap maka perusahaan memiliki manajemen aset yang baik, dimana semua aset yang dimiliki perusahaan digunakan secara efektif dan efesien, sehingga tidak ada aset yang menumpuk atau aset yang tidak digunakan. Dikarenakan perputaran aktiva yang tinggi maka pemasukan kas pun meningkat akibat dari oprasional perusahaan yang berjalan dengan tepat dan tinggi juga.

\section{Pengaruh Perputaran Piutang dan Perputaran Aktiva Tetap Terhadap Profitabilitas}

Berdasarkan hasil pengujian simultan (uji F), diketahui hasil dari $\mathrm{F}$ hitung sebesar 12,944 dan F tabel sebesar 3,295, dimana hasil F hitung lebih besar daripada F tabel $(12,944>3,295)$ dan memiliki nilai signifikan sebesar 0,000 dengan nilai tingkat signifikan lebih kecil dari 0,05, sehingga dapat diartikan bahwa adanya pengaruh secara simultan (bersama-sama) antara perputaran piutang dan perputaran aktiva tetap terhadap profitabilitas secara signifikan.

Berdasarkan uji korelasi ganda (uji R), diperoleh nilai $\mathrm{R}$ sebesar 0,669 yang berarti hubugan yang kuat antara perputaran piutang dan perputaran aktiva tetap terhadap profitabilitas.

Berdasarkan uji koefisien determinasi (uji Adjusted R2) diperoleh nilai Adjusted R2 sebesar 0,413 dimana dalam presentase menjadi 41,3\%. Hal ini menunjukan bahwa presentase hubungan perputaran piutang dan perputaran aktiva tetap terhadap profitabilitas sebesar 41,3\%, sedangkan sisanya sebesar 58,7\% (100\% $41,3 \%$ ) dipengaruhi oleh variabel lain yang tidak dimasukkan dalam variabel penelitian ini.

\section{KESIMPULAN}

Berdasarkan penjelasan-penjelasan di atas terhadap penelitian pengaruh perputaran piutang dan perputaran aktiva tetap terhadap profitabilitas pada perusahaan publik dengan sub sektor perdagangan eceran yang terdaftar di Bursa Efek Indonesia dengan periode tahun 2013 sampai dengan 2017, maka terjawab sudah rumusan masalah dari penelitian ini dan dapat disimpulkan sebagai berikut: 
1. Terdapat pengaruh perputaran piutang terhadap profitabilitas

2. Terdapat pengaruh perputaran aktiva tetap terhadap profitabilitas.

3. Terdapat pengaruh perputaran piutang dan aktiva tetap terhadap profitabilitas.

\section{DAFTAR PUSTAKA}

Ainiyah, Q., \& Khuzaini. (2016). Pengaruh Perputaran Piutang, Perputaran Persediaan Dan Debt To Equity Ratio Terhadap Profitabilitas. Jurnal Ilmu Dan Riset Manajemen, 5(1), 1-19.

Ansofino, Jolianis, Yolamalinda, and Hagi Afrilindo. Buku Ajar Ekonometrika. Yogyakarta: Deepublish, 2016.

Brigham, Eugene F., and Joel F. Houston. Dasar - Dasar Manajemen Keuangan. Jakarta: Salemba Empat, 2014.

Fahmi, Irham. Pengantar Manajemen Keuangan. Bandung: Alfabeta cv, 2016.

Ferdinand, Augusty. METODE PENELITIAN MANAJEMEN. Pedoman Penelitian untuk Penulisan Skripsi, Tesis dan Disertasi Ilmu Manajemen. Semarang: Badan Penerbit Universitas Diponegoro, 2014.

Ghozali, Imam. Aplikasi Analisis Multivariate dengan Program IBM SPSS 23. Semarang: Badan Penerbit Universitas Diponegoro, 2013.

Harjito, Agus, and Martono. Manajemen Keuangan. Yogyakarta: Ekonisia, 2014.

Hery. Analisis Laporan Keuangan. Yogyakarta: Center for Academic Publishing Service, 2015.

Hoiriya, \& Lestariningsih, M. (2015). PENGARUH PERPUTARAN MODAL KERJA, PERPUTARAN PIUTANG, PERPUTARAN PERSEDIAAN TERHADAP PROFITABILITAS PERUSAHAAN MANUFAKTUR. Jurnal Ilmu Dan Riset Manajemen, 4(4), 1-15.

Kasmir. Pengantar Manajemen Keuangan. Jakarta: Kecana Pranada Media Group, 2016.

Lubis, Mayang Sari. Metodologi Penelitian. Yogyakarta: Deepublish, 2018.

Musthafa. Manajemen Keuangan. Yogyakarta: Andi, 2017.

Oxtaviana, T. A., \& Khusbandiyah, A. (2016). Pengaruh Aktiva Tetap, Hutang Jangka Panjang Dan Perputaran Modal Kerja Terhadap Profitabilitas Pada Perusahaan Manufaktur Yang Terdaftar Di BEI. Kompartemen, XIV(1), 1-19.

Priyanto, Duwi. Seri CD Software OLAH DATA STATISTIK DENGAN PROGRAM PSPP ALTERNATIF SPSS. Yogyakarta: MediaKom, 2013.

Sodiq, A. M., \& Fitria, A. (2015). Pengaruh Rasio Aktivitas Terhadap Profitabilitas Pada Perusahaan Food And Beverages. Jurnal Ilmu Dan Riset Akuntansi, 4(3).

Sutrisno. Manajemen Keuangan : Teori, Konsep, dan Aplikasi. Yogyakarta: Ekonisia, 2017.

Timotius, Kris H. Pengantar Metodologi Penelitian: Pendekatan Manajemen Pengetahuan untuk Perkembangan Pengetahuan. Yogyakarta: Andi, 2017.

Verawati, V. L., \& Oetomo, H. W. (2014). Pengaruh Perputaran Modal Kerja, Perputaran Piutang, dan Perputaran Persedian Terhadap Profitabilitas Perusahaan Tekstil. Jurnal Ilmu Dan Riset Manajemen, 3(9), 1-20.

Zatira, D. (2017). PENGARUH PERPUTARAN MODAL KERJA DAN

PERPUTARAN AKTIVA TETAP TERHADAP PROFITABILITAS (Pada Perusahaan 
PRIMANOMICS : JURNAL EKONOMI DAN BISNIS - VOL. 17. NO. 3 (2019)

Versi Online Tersedia di : https://jurnal.ubd.ac.id/index.php/ds

| 1412-632X (Cetak) | 2614-6789 (Online) |

Food and Beverages yang Terdaftar di Bursa Efek Indonesia Pada Tahun 2009-2015). Dynamic Management Journal, 1(1). 